\title{
Oxidative Stress and Mitogen-Activated Protein Kinase Phosphorylation Mediate Ammonia-Induced Cell Swelling and Glutamate Uptake Inhibition in Cultured Astrocytes
}

\author{
A. R. Jayakumar, ${ }^{1}$ K. S. Panickar, ${ }^{1}$ Ch. R. K. Murthy, ${ }^{\dagger}$ and M. D. Norenberg ${ }^{1,2,3}$ \\ Departments of ${ }^{1}$ Pathology and ${ }^{2}$ Biochemistry and Molecular Biology, University of Miami School of Medicine, ${ }^{3}$ Veterans Affairs Medical Center, Miami, \\ Florida 33101, and ${ }^{4}$ Department of Animal Sciences, University of Hyderabad, India, 500046
}

\begin{abstract}
Hepatic encephalopathy (HE) is a major neurological complication in patients with severe liver failure. Elevated levels of ammonia have been strongly implicated as a factor in HE, and astrocytes appear to be the primary target of its neurotoxicity. Mechanisms mediating key aspects of ammonia-induced astrocyte dysfunction such as cell swelling and inhibition of glutamate uptake are not clear. We demonstrated previously that cultured astrocytes exposed to ammonia increase free radical production. We now show that treatment with antioxidants significantly prevents ammonia-induced astrocyte swelling as well as glutamate uptake inhibition. Because one consequence of oxidative stress is the phosphorylation of mitogen-activated protein kinases (MAPKs), we investigated whether phosphorylation of MAPKs may mediate astrocyte dysfunction. Primary cultured astrocytes exposed to $5 \mathrm{~mm} \mathrm{NH}_{4} \mathrm{Cl}$ for different time periods (1-72 h) significantly increased phosphorylation of extracellular signal-regulated kinase $1 / 2$ (ERK1/2), p38 ${ }^{\mathrm{MAPK}}$, and c-Jun N-terminal kinase (JNK) $1 / 2 / 3$, which was inhibited by appropriate MAPK inhibitors 1, 4-diamino-2, 3-dicyano-1, 4-bis (2-aminophenylthio) butadiene (U0126; for ERK1/2), trans-1-(4-hydroxyclyclohexyl)-4-(4-fluorophenyl)-5-(2-methoxypyrimidin-4-yl)imidazole (SB 239063; for p38 $\left.{ }^{\mathrm{MAPK}}\right)$, and anthra[1,9-cd]pyrazol-6(2H)-one (SP600125; for JNK1/2/3), as well as by antioxidants. Kinase inhibitors partially or completely prevented astrocyte swelling. Although SB239063 and SP600125 significantly reversed glutamate uptake inhibition and ammonia-induced decline in glutamate-aspartate transporter protein levels, U0126 did not, indicating a differential effect of these kinases in ammonia-induced astrocyte swelling and glutamate transport impairment. These studies strongly suggest the involvement of oxidative stress and phosphorylation of MAPKs in the mechanism of ammonia-induced astrocyte dysfunction associated with ammonia neurotoxicity.
\end{abstract}

Key words: ammonia; astrocyte swelling; glutamate uptake; oxidative stress; MAP kinases; hepatic encephalopathy

\section{Introduction}

Liver failure is the fourth leading cause of death in the United States and is an important cause of morbidity and mortality among the poor (Lockwood, 1992). Approximately $50-75 \%$ of these individuals have varying degrees of neurological symptoms resulting in a condition known as hepatic encephalopathy (HE). HE can present acutely [fulminant hepatic failure (FHF)] resulting from massive liver necrosis after viral hepatitis, acetaminophen toxicity, or exposure to other hepatotoxins. It presents with the abrupt onset of delirium, seizures, and coma and has an extremely poor prognosis with an $80-90 \%$ mortality rate (Capocaccia and Angelico, 1991). The only effective treatment for this condition is an emergency liver transplantation (Bismuth et al.,

\footnotetext{
Received 0ct. 5, 2005; revised Feb. 27, 2006; accepted March 2, 2006.

This work was supported by a Merit Review from the Department of Veterans Affairs and by National Institutes of Health Grant DK063311. A.R.J. is supported by the American Association for the Study of Liver Disease/American Liver Foundation Grant. We thank Dr. Chang Kim and Alina Fernandez-Revuelta for the preparation of cell cultures. We also thank Jan Kelly for assistance with Western blot quantitation.

${ }^{\dagger}$ Deceased Dec. 1, 2003.

Correspondence should be addressed to Dr. Michael D. Norenberg, Department of Pathology (D-33), University of Miami School of Medicine, P.O. Box 016960, Miami, FL 33101. E-mail: mnorenbe@med.miami.edu. DOI:10.1523/JNEUROSCI.0120-06.2006

Copyright $\odot 2006$ Society for Neuroscience $\quad$ 0270-6474/06/264774-11\$15.00/0
}

1996). Chronic HE (portal-systemic encephalopathy) is characterized by change in personality, altered mood, diminished intellectual capacity, abnormal muscle tone and tremor (asterixis), stupor, and coma (Plum and Hindfelt, 1976).

Although the pathogenetic factors responsible for HE are still not clearly known, elevated levels of brain ammonia resulting from failure of the liver to detoxify it has been strongly implicated as an important element in this condition (for review, see Albrecht and Jones, 1999; Hazell and Butterworth, 1999). Agents and experimental procedures that increase blood or brain ammonia reproduce clinical and pathological changes observed in HE. Likewise, patients with hereditary hyperammonemia have similar clinical and pathological changes as found in HE. Exposure of cultured astrocytes to ammonia mimics many of the changes observed in HE in vivo. However, mechanisms by which ammonia exerts its neurotoxicity still remain poorly understood. Views have ranged from electrophysiological disturbance (Raabe, 1989), neurotransmitter dysfunction (Butterworth, 2001), excitotoxicity (Marcaida et al., 1992), and more recently oxidative stress (Norenberg, 2003).

Brain edema with increased intracranial pressure and brain herniation is the major clinical complication associated with acute HE (Vaquero et al., 2003). Although the basis for such 
edema remains to be determined, it is clear that swelling of astrocytes represents a major component of the edema (Martinez, 1968; Norenberg, 1977, 2001; Traber et al., 1989). Mechanisms underlying such astrocyte swelling in acute HE are still not well understood, although elevated brain ammonia levels are likely involved. Increased brain water has been described in dogs with urease-induced hyperammonemia (Levin et al., 1989), as well as in rats after ammonium acetate infusions (Takahashi et al., 1991). Treatment of cerebral cortical slices with ammonia in concentrations equivalent to those reported in brain in experimental FHF resulted in significant swelling and concomitant reductions of the inulin space (Ganz et al., 1989). Similarly, swelling of cerebral cortical astrocytes was observed after ammonia infusion in primates (Voorhies et al., 1983), as well as in cultured astrocytes (Norenberg et al., 1991; Zwingmann et al., 2000).

Another aspect of HE is a decline in glutamate transport by astrocytes, which may result in elevated extracellular glutamate levels and lead to abnormalities in glutamatergic neurotransmission. Thus, whereas total brain glutamate levels are decreased in various models of HE (Hindfelt et al., 1977; Bosman et al., 1990; Dejong et al., 1992), extracellular glutamate levels are consistently increased in rat models of acute liver failure (Moroni et al., 1983; Tossman et al., 1987; de Knegt et al., 1994). Ammonia has been shown to suppress high affinity glutamate uptake (Bender and Norenberg, 1996). Likewise, downregulation of the glutamate transporter GLT-1 [excitatory amino acid transporter 2 (EAAT-2)] has been shown in hyperammonemic rats, in rats with portacaval anastomosis (model of chronic HE), as well as in thioacetamide-induced acute liver failure (Knecht et al., 1997; Norenberg et al., 1997). A decrease in glutamate-aspartate transporter (GLAST) (EAAT-1) mRNA levels was found in cultured astrocytes exposed to a pathophysiological concentration of ammonia (Zhou and Norenberg, 1999).

The mechanism(s) by which ammonia induces astrocyte swelling and glutamate uptake inhibition is unclear. Oxidative stress has been hypothesized to play an important role in the pathogenesis of ammonia neurotoxicity (Norenberg, 2003). One important consequence of oxidative stress is the phosphorylation of mitogen-activated protein kinases (MAPKs), including p38 ${ }^{\mathrm{MAPK}}$, c-Jun N-terminal kinase (JNK), and the extracellular signal-regulated kinase (ERK) (Kyriakis and Avruch, 1996; Aikawa et al., 1997; Mielke and Herdegen, 2000; Ono and Han, 2000). Such MAPK phosphorylation has also been shown in cultured astrocytes in response to oxidant signaling (Luo and Roth, 2000; Mizuhashi et al., 2000; S. H. Chen et al., 2001; Lennon et al., 2002).

In this study, we investigated whether MAPK phosphorylation occurs in ammonia-treated astrocytes and whether such phosphorylation mediates key aspects of ammonia-induced astrocyte dysfunction. Our findings indicate that antioxidants reduce ammonia-induced astrocyte swelling and glutamate uptake inhibition; that MAPK phosphorylation occurs after ammonia treatment, a process which is inhibited by antioxidants; and that inhibition of MAPKs attenuates aspects of ammonia-induced astrocyte dysfunction. These studies indicate an important role for oxidative stress and MAPK activation in the mechanism of ammonia neurotoxicity.

\section{Materials and Methods}

Astrocyte cultures. Primary cultures of cortical astrocytes were prepared as described previously (Ducis et al., 1990). Briefly, brains of 1- to 2-d-old rat pups were seeded on $35 \mathrm{~mm}$ culture dishes in DMEM containing penicillin, streptomycin, and $15 \%$ fetal bovine serum and incubated at $37^{\circ} \mathrm{C}$ with $5 \% \mathrm{CO}_{2}$ and $95 \%$ air. The culture media were changed twice weekly. Cultures consisted of 95-99\% astrocytes as determined by glial fibrillary acidic protein (GFAP) immunohistochemistry. All cultures used in the experiments were $25-30 \mathrm{~d}$ old. Procedures followed guidelines established by National Institute of Health Guide for the Care and use of Laboratory Animals and were approved by the local animal care committee (Institutional Animal Care and Use Committee).

Cell volume determination. Cell volume was estimated by measuring the intracellular water space by the method of Kletzein et al. (1975), as modified by Kimelberg (1987) and Bender and Norenberg (1998). Briefly, $1 \mathrm{~mm} 3$-O-methylglucose (3-OMG) and $0.5 \mu \mathrm{Ci} / \mathrm{ml}\left[{ }^{3} \mathrm{H}\right]-3-$ OMG were added to the culture $6 \mathrm{~h}$ before the volume assay. At the end of the incubation period, culture medium was aspirated, and an aliquot was saved for radioactivity determination. Cells were rapidly washed six times with ice-cold buffer containing $229 \mathrm{~mm}$ sucrose, $1 \mathrm{~mm}$ Tris-nitrate, $0.5 \mathrm{~mm}$ calcium nitrate, and $0.1 \mathrm{~mm}$ phloretin, $\mathrm{pH}$ 7.4. Cells were harvested into $0.5 \mathrm{ml}$ of $1 \mathrm{~N}$ sodium hydroxide. Radioactivity in the cell extracts and medium were determined, and an aliquot of the cell extract was used for protein estimation with the Bio-Rad bicinchoninic acid kit. Values were normalized to protein level, and cell volume was expressed as microliters/milligram protein.

Western blots. Astrocytes were solubilized in lysis buffer: $125 \mathrm{~mm}$ Tris$\mathrm{HCl} 6.8 ; 4 \%$ SDS, phosphatase inhibitors, and protease inhibitor mixture (Roche Products, Indianapolis, IN). Lysates were centrifuged at 10,000 rpm for $6 \mathrm{~min}$, and protein levels were measured by the BCA method. Equal amounts of protein (10 $\mu \mathrm{g}$ of total protein per lane) were subjected to SDS-PAGE using $12 \%$ gels (Tris- $\mathrm{HCl}$ ) and then electrophoretically transferred to a nitrocellulose membrane. Blots were blocked with $5 \%$ nonfat dry milk in TBS-T (TBS; $20 \mathrm{~mm}$ Tris- $\mathrm{HCl}, 150 \mathrm{~mm} \mathrm{NaCl}, \mathrm{pH}$ 7.4, and $0.05 \%$ Tween 20 ) for $2 \mathrm{~h}$ at room temperature and then incubated with respective primary antibodies at $4^{\circ} \mathrm{C}$ overnight. Membranes were washed with TBS-T and incubated with HRP-conjugated secondary antibodies for $2 \mathrm{~h}$ at room temperature. After washing, membranes were visualized using enhanced chemiluminescence reagents (ECL-plus; Amersham Biosciences, Piscataway, NJ). Primary antibodies to detect only phosphorylated forms of ERK1/2, p38 $8^{\text {MAPK }}$, and JNK1/2/3 as well as total ERK1/2, p38 ${ }^{\mathrm{MAPK}}$, and JNK1/2/3 were purchased from Cell Signaling Technology (Beverly, MA). Anti-GLAST antibody was purchased from Chemicon (Temecula, CA). Anti- $\alpha$-tubulin antibody was obtained from Oncogene (San Diego, CA). All primary antibodies were used at 1:1000 dilutions. Anti-rabbit, anti-mouse (Vector Laboratories, Burlingame, CA), and anti-guinea pig (Santa Cruz Biotechnology, Santa Cruz, CA) HRP-conjugated secondary antibodies were used at 1:1000. Optical density of the bands was measured with the Chemi-Imager digital imaging system (Alpha Innotech, San Leandro, CA), and results were quantified with Sigma (St. Louis, MO) Scan Pro as a proportion of the signal of a house-keeping protein band ( $\alpha$-tubulin). Controls, which included omission of the primary antibodies, did not show any band.

Measurement of glutamate uptake. L-Glutamate uptake studies were done as described by Drejer et al. (1982) and Bender et al. (1989). Assays were done in DMEM at $37^{\circ} \mathrm{C}$ in $5 \% \mathrm{CO}_{2} / 95 \%$ air. Uptake experiments were initiated by adding $50 \mu \mathrm{M}$ and $7.4 \mathrm{MBq} / \mathrm{L} \mathrm{D}-\left[{ }^{3} \mathrm{H}\right]$ aspartate (a nonmetabolizable analog of $\mathrm{L}-\left[{ }^{3} \mathrm{H}\right]$ glutamic acid) to the media for $1 \mathrm{~min}$. The uptake reaction was terminated by washing cells rapidly three times in ice-cold DMEM. Cells were then harvested into $500 \mu \mathrm{l}$ of $1 \mathrm{~N} \mathrm{NaOH}$ solution and mixed thoroughly by vortexing. Separate aliquots were taken for protein determination and liquid scintillation spectroscopy. Uptake rates were calculated from the measured radioactivity of the cells and the specific activity of the media, and the results were expressed as $\mathrm{nmol} / \mathrm{min} / \mathrm{mg}$ protein.

Statistical analysis. Each group consisted of four to five culture dishes per experiment for each time point studied for the cell swelling and glutamate uptake experiments. At least two to four plates were used for Western blot analysis. Experiments were performed from four to seven separate seedings. The extent of cell swelling and glutamate uptake rates obtained were normalized to protein values and subjected to ANOVA followed by Tukey's post hoc comparisons. Intensity unit values obtained from optical density of the bands in Western blots were also subjected to ANOVA followed by Tukey's post hoc comparison test and were ex- 


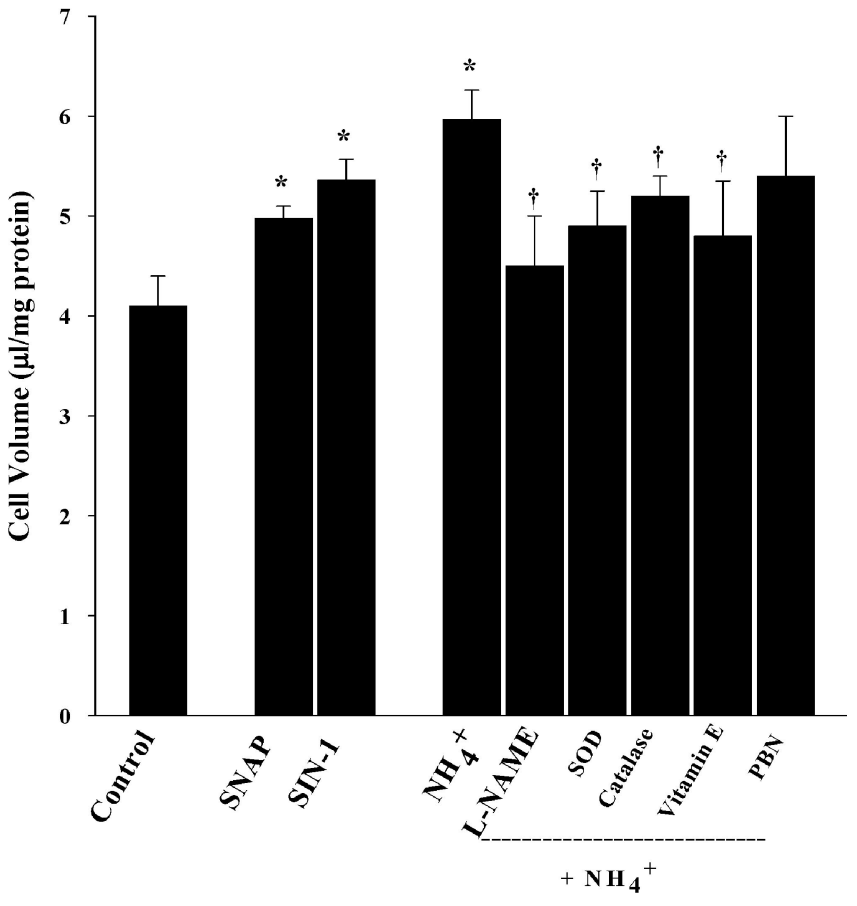

Figure 1. Reduction of ammonia-induced astrocyte swelling by antioxidants. Cultured astrocytes exposed to $5 \mathrm{~mm} \mathrm{NH}_{4} \mathrm{Cl}$ significantly increased cell swelling (2d). Similarly, NO donors SNAP $(25 \mu \mathrm{m})$ and SIN-1 $(500 \mu \mathrm{M})$ also significantly increased astrocyte swelling. Treatment with SOD $(25 \mathrm{U} / \mathrm{ml})$, catalase $(250 \mathrm{U} / \mathrm{ml})$, vitamin $\mathrm{E}(100 \mu \mathrm{m})$, and the NOS inhibitor L-NAME $(250 \mu \mathrm{m})$ significantly diminished ammonia-induced astrocyte swelling. PBN (500 $\mu \mathrm{m})$ had no significant effect on swelling. ANOVA, $n=4$. $^{*} p<0.05$ versus control; ${ }^{\dagger} p<0.05$ versus $\mathrm{NH}_{4} \mathrm{Cl}$. Error bars represent mean \pm SEM.

pressed as percentage change over control. At each time point, the experimental cultures were compared with their respective control.

\section{Results}

Antioxidants and nitric oxide synthase inhibition attenuate ammonia-induced astrocyte swelling

Astrocyte swelling in cultures, after treatment with $5 \mathrm{~mm}$ ammonia, is first observed at $12 \mathrm{~h}$ (Rama Rao et al., 2003), but it peaks at $48 \mathrm{~h}$. All studies for assessing swelling used the $48 \mathrm{~h}$ time point. To investigate the role of oxidative stress in ammonia-induced astrocyte swelling, primary astrocyte cultures were treated for $2 \mathrm{~d}$ with a pathophysiological concentration of ammonia $\left(\mathrm{NH}_{4} \mathrm{Cl} ; 5 \mathrm{~mm}\right)$; such value is commonly found in brains of animals with acute liver failure (Swain et al., 1992). Antioxidant treatment was done in the presence or absence of different concentrations of individual antioxidants, including superoxide dismutase (SOD; 10, 25, and $100 \mathrm{U} / \mathrm{ml}$ ), catalase $(250,500$, and $1000 \mathrm{U} / \mathrm{ml}), \alpha$-tocopherol (vitamin E; 50,100 , and $250 \mu \mathrm{M}$ ), or $N$-tert-butyl- $\alpha$-phenylnitrone (PBN; $100,250$, and $500 \mu \mathrm{M})$, a spin trapping free radical scavenger as well as L-NAME (250 and $500 \mu \mathrm{M})$, a nitric oxide (NO) synthase (NOS) inhibitor. Control plates were treated with the same volume of respective solvents (vehicle). Ammonia (5 $\mathrm{mm}$ ) increased cell swelling by $41 \%$ compared with controls $(p<0.05)$ (Fig. 1). Treatment with antioxidants and $\mathrm{N}$-nitroL-arginine methyl ester (L-NAME) significantly reduced ammonia-induced swelling. L-NAME at $250 \mu \mathrm{M}$ decreased ammonia-induced swelling by $76 \%(p<0.05)$ (Fig. 1). Lesser reduction of swelling was observed with $100 \mu \mathrm{M}$ vitamin $\mathrm{E}$ (52\%; $p<0.05), 25 \mathrm{U} / \mathrm{ml} \mathrm{SOD} \mathrm{(48 \% ;} p<0.05)$, and $250 \mathrm{U} / \mathrm{ml}$ catalase $(35 \% ; p<0.05)$. Although PBN at $250 \mu \mathrm{M}$ diminished

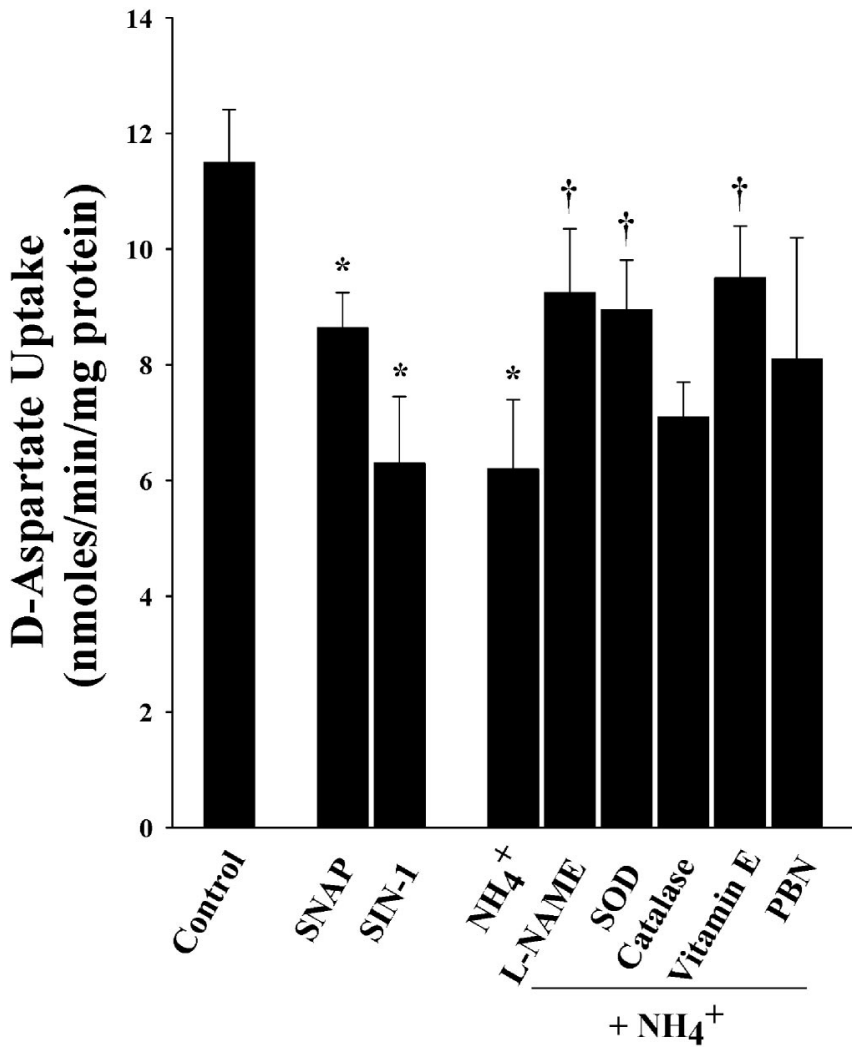

Figure 2. Effect of antioxidants on ammonia-induced glutamate uptake inhibition in cultured astrocytes. A 45\% decrease in glutamate uptake was observed when cells were exposed to $5 \mathrm{~mm} \mathrm{NH}_{4} \mathrm{Cl}(3 \mathrm{~d})$. NO donors, SNAP $(25 \mu \mathrm{m})$, and SIN-1 (500 $\left.\mu \mathrm{m}\right)$ also decreased glutamate uptake significantly. Treatment with SOD $(25 \mathrm{U} / \mathrm{ml})$, vitamin E $(100 \mu \mathrm{m})$, and L-NAME partially prevented the ammonia-induced glutamate uptake inhibition. PBN (500 $\mu \mathrm{m})$ had no significant effect on glutamate uptake inhibition. ANOVA, $n=11$. ${ }^{*} p<0.05$ versus control; ${ }^{\dagger} p<$ 0.05 versus ammonia. Error bars represent mean \pm SEM.

cell swelling by $27 \%$, this decrease was not significant (Fig. 1). PBN at 100 or $500 \mu \mathrm{M}$ also did not inhibit ammonia-induced astrocyte swelling. Cultures treated with the same volume of respective solvents or with antioxidants alone did not change cell volume.

Because the magnitude of protection by L-NAME in diminishing astrocyte swelling was more than other antioxidants, we tested whether NO donors cause astrocyte swelling. Astrocytes exposed to $S$-nitroso- $N$-acetyl penicillamine (SNAP; $25 \mu \mathrm{M}$ ) or 3-morpholinosydnoimine $\mathrm{HCl}(\mathrm{SIN}-1 ; 500 \mu \mathrm{M})$ for $48 \mathrm{~h}$ increased astrocyte swelling by $21.4 \pm 3.6$ and $30.7 \pm 4.5 \%$, respectively, when compared with controls (both, $p<0.05$ ) (Fig. 1).

\section{Antioxidants and NOS inhibition diminish ammonia-} induced glutamate uptake inhibition

Inhibition of glutamate uptake by $5 \mathrm{~mm}$ ammonia occurs at $24 \mathrm{~h}$, the earliest time point investigated (Bender and Norenberg, 1996), but it peaks at $72 \mathrm{~h}$. To determine whether antioxidants prevent ammonia-induced glutamate uptake inhibition, cultures were treated with different antioxidants, $\operatorname{SOD}(10,25,50$, and 100 $\mathrm{U} / \mathrm{ml})$, catalase $(100,250,500$, and $1000 \mathrm{U} / \mathrm{ml})$, vitamin $\mathrm{E}(50$, 100 , and $250 \mu \mathrm{M})$, PBN $(100,250$, and $500 \mu \mathrm{M})$, as well as L-NAME $(100,250$, and $500 \mu \mathrm{M})$ with or without ammonia for $3 \mathrm{~d}$. Control plates were treated with the same volume of respective solvents. The rate of uptake was performed at $1 \mathrm{~min}$. Astrocytes exposed to ammonia significantly decreased D-aspartate uptake by $46 \%$ compared with controls $(p<0.05)$ (Fig. 2). This 

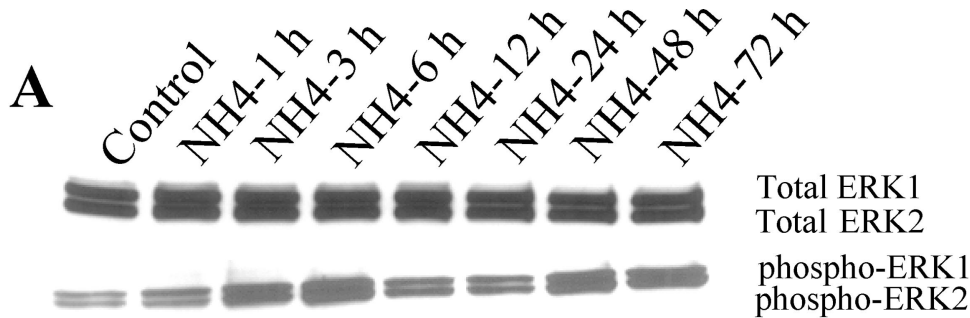

$\mp-\div-\frac{\text { phospho-ERK1+UO126 }}{\text { phospho-ERK2+UO126 }}$
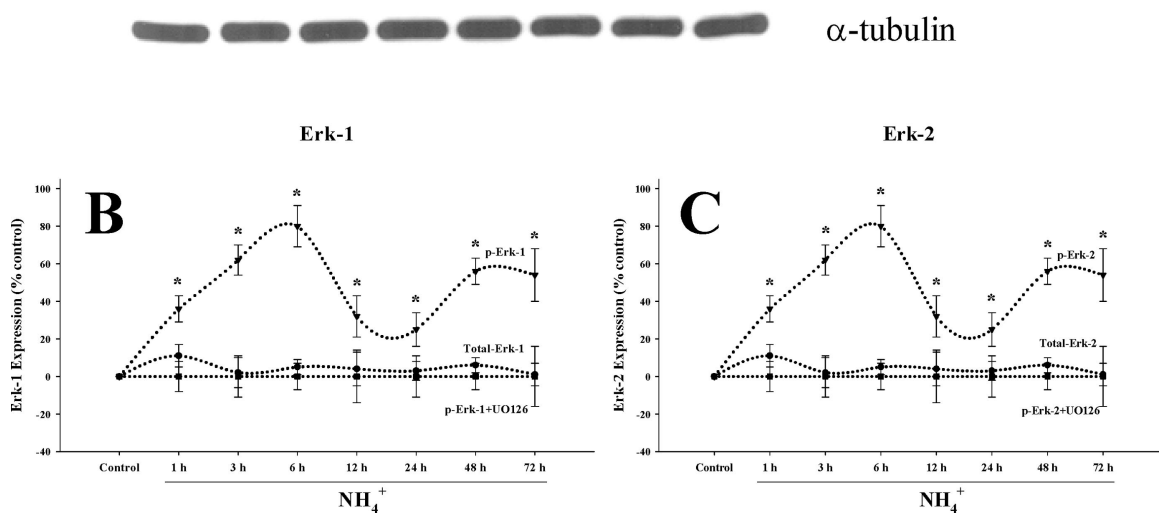

Figure 3. Time course of ERK activation by ammonia in cultured astrocytes. $A$, Western blots reveal no significant change in total ERK1/2 level when cultures were exposed to $5 \mathrm{~mm} \mathrm{NH}_{4} \mathrm{Cl}$. A sustained increase in the level of phospho-ERK1/2 was observed after ammonia treatment. U0126, an ERK1/2 inhibitor, prevented the $\mathrm{NH}_{4} \mathrm{Cl}$-induced ERK1/2 phosphorylation. B, C, Quantitation of $\mathrm{NH}_{4} \mathrm{Cl}$-induced phospho-ERK1 $(\boldsymbol{B})$ and phospho-ERK2 ( $\boldsymbol{C}$ levels in astrocytes with and without the ERK1/2 inhibitor. PhosphoERK1/2 levels are normalized against $\alpha$-tubulin. ANOVA, $n=4 .{ }^{*} p<0.05$ versus control; ${ }^{\dagger} p<0.05$ versus phospho-ERK. U0, U0126. Error bars represent mean \pm SEM.

inhibition was significantly reversed by treatment with $25 \mathrm{U} / \mathrm{ml}$ SOD, $250 \mu \mathrm{M} \mathrm{L}-\mathrm{NAME}$, and $100 \mu \mathrm{M}$ vitamin $\mathrm{E}(36,54$, and $47 \%$, respectively; $p<0.05$ ) (Fig. 2). Catalase or PBN did not significantly reverse the ammonia-induced glutamate uptake inhibition. Similar to the observation with astrocyte swelling, L-NAME was effective in abrogating ammonia-induced glutamate uptake inhibition. To determine whether SNAP and SIN-1 can also inhibit glutamate uptake, we examined their effect in cultured astrocytes. Results showed a $24.9 \pm 4.2$ and $36 \pm 2.7 \%$ inhibition of glutamate uptake with SNAP and SIN-1, respectively, when compared with controls (both, $p<0.05$ ) (Fig. 2).

Ammonia increases phosphorylation of MAPKs in astrocytes Because oxidative stress has been shown to activate MAPKs, including $\mathrm{p} 38^{\mathrm{MAPK}}, \mathrm{JNK} 1 / 2 / 3$, and ERK1/2, we examined whether MAPK phosphorylation also occurs after ammonia treatment. Cultured astrocytes were exposed to $5 \mathrm{mM} \mathrm{NH}_{4} \mathrm{Cl}$ for different time periods $(1,3,6,12,24,48$, and $72 \mathrm{~h})$. Changes in total and phosphorylated ERK1/2, JNK1/2/3, and p38 ${ }^{\mathrm{MAPK}}$ were determined by Western blots. Ammonia significantly increased the phosphorylation of ERK1/2 at all time points. Peak phosphorylation was observed at $6 \mathrm{~h}$, after which there was a decline at 12-24 h with a subsequent increase at $48-72 \mathrm{~h}$ (Fig. 3). Increased phosphorylation of $\mathrm{p} 38^{\mathrm{MAPK}}$ was observed at $1 \mathrm{~h}$ after ammonia treatment, which generally remained elevated at this level at all time points ( $p<0.05$ vs control) (Fig. 4$)$. In contrast, the peak increase in phosphorylation of JNK $1 / 2 / 3$ was observed at $3 \mathrm{~h}$, followed by a subsequent decline (Fig. 5). Total ERK1/2, p38 $8^{\mathrm{MAPK}}$, and JNK1/2/3 expression did not change at any time point during ammonia treatment. These results demonstrate a differential temporal pattern of phosphorylation of MAPKs in cultures exposed to ammonia.

\section{Antioxidants and NOS inhibition attenuate ammonia-induced MAPK phosphorylation}

To determine whether oxidative stress contributes to ammonia-induced MAPK phosphorylation in cultured astrocytes, we examined the effect of various antioxidants, including SOD (25 and $50 \mathrm{U} / \mathrm{ml}$ ), catalase $(250,500$, and $1000 \mathrm{U} / \mathrm{ml})$, vitamin E (100 and $250 \mu \mathrm{M}), \operatorname{PBN}(50,100$, and $250 \mu \mathrm{M}$ ), and the NOS inhibitor L-NAME $(100,250$, and $500 \mu \mathrm{M})$ on ERK1/2, JNK1/2/3, and p38 ${ }^{\text {MAPK }}$ phosphorylation. Treatment with SOD and L-NAME, but not the other antioxidants, significantly attenuated ammoniainduced ERK1/2 phosphorylation at the dose of $(25 \mathrm{U} / \mathrm{ml}$ and $250 \mu \mathrm{M}$, respectively). All antioxidants, SOD (20 U/ml), catalase $(250 \mathrm{U} / \mathrm{ml})$, vitamin $\mathrm{E}(100 \mu \mathrm{M})$, as well as L-NAME $(250 \mu \mathrm{M})$ significantly decreased phosphorylation of both JNK1/ $2 / 3$ and p38 ${ }^{\mathrm{MAPK}}$ (Fig. 6). Astrocytes treated with $\mathrm{PBN}$ had no effect on ammonia-induced ERK1/2, JNK1/2/3, and $\mathrm{p} 38^{\mathrm{MAPK}}$ phosphorylation.

\section{MAPK inhibitors decrease ammonia- induced phosphorylation of MAPK and}

\section{astrocyte swelling}

We then examined whether MAPK phosphorylation contributes to ammonia-induced astrocyte swelling. Experiments to test the ability of various agents to inhibit phosphorylation of MAPKs in astrocytes were conducted with MAPK inhibitors. Cultures were treated with the following: 1-100 $\mu \mathrm{M}$ 1, 4-diamino-2, 3-dicyano-1, 4-bis (2-aminophenylthio) butadiene (UO126), an inhibitor of MAP kinase kinase 1/2 (MEK1/2), the upstream kinase that activates ERK1/2; trans-1-(4-hydroxyclyclohexyl)-4(4-fluorophenyl)-5-(2-methoxypyrimidin-4-yl)imidazole (SB 239063 ; $1-100 \mu \mathrm{M}$, an inhibitor of $\left.\mathrm{p} 38^{\mathrm{MAPK}}\right)$, and anthra[1,9$c d$ pyrazol-6(2H)-one (SP600125; 1-100 $\mu \mathrm{M}$, an inhibitor of JNK1/2/3), with and without ammonia. When compared with cells treated with ammonia, UO126 $(10 \mu \mathrm{M})$ prevented the phosphorylation of both ERK1/2 (Fig. 3). Similarly, cells treated with SB239063 $(10 \mu \mathrm{M})$ prevented ammonia-induced p38 ${ }^{\text {MAPK }}$ phosphorylation (Fig. 4). Although both JNK1 and JNK2 were phosphorylated in response to ammonia, the JNK inhibitor SP600125 (1 $\mu \mathrm{M})$ only partially diminished the phosphorylation of JNK1, and it did not prevent phosphorylation of JNK2 or JNK3 (Fig. 5). Doses $>1 \mu \mathrm{M}$ either had no additional effect on JNK phosphorylation $(5 \mu \mathrm{M})$ or resulted in astrocyte death $(100 \mu \mathrm{M})$. Cultures treated with vehicle had no effect on MAPK phosphorylation. Doses that prevented MAPK phosphorylation from these experiments were chosen for subsequent studies (10 $\mu \mathrm{M}$ UO126; $10 \mu \mathrm{M} \mathrm{SB} 239063 ; 1 \mu \mathrm{M}$ SP600125), unless noted otherwise.

Cultures were treated with the above-mentioned MAPK inhibitors with and without $5 \mathrm{mM} \mathrm{NH}_{4} \mathrm{Cl}$. Astrocytes treated with $5 \mathrm{mM} \mathrm{NH}_{4} \mathrm{Cl}$ for $48 \mathrm{~h}$ increased cell volume (45\% over 
control; $p<0.05$ vs control). Treatment of cultures with UO126 $(10 \mu \mathrm{M})$ and SB239063 (10 $\mu \mathrm{M})$ completely prevented ammonia-induced astrocyte swelling $\left(p<0.05\right.$ vs $\left.\mathrm{NH}_{4} \mathrm{Cl}\right)$. In contrast, the JNK inhibitor SP600125 (1 $\mu \mathrm{M})$ only partially prevented ammonia-induced astrocyte swelling (56\%; $p<0.01$ compared with $\mathrm{NH}_{4} \mathrm{Cl}$ alone). SP600125 (5 $\mu \mathrm{M})$ did not inhibit swelling (Fig. 7).

To determine the significance of the early phosphorylation of MAPKs in ammonia-induced swelling, we added MAPK inhibitors immediately after the occurrence of the peak phosphorylation (ERK $1 / 2$ at $6 \mathrm{~h}, \mathrm{p} 38^{\mathrm{MAPK}}$ at $1 \mathrm{~h}$, and JNK $1 / 2 / 3$ at $3 \mathrm{~h}$ ). The results showed that delayed addition of these inhibitors did not reduce astrocyte swelling. Furthermore, a lower dose of ammonia $(2 \mathrm{~mm})$ that did not cause significant astrocyte swelling also did not result in phosphorylation of MAPKs at early time points $(1,3$, and $6 \mathrm{~h}$; data not shown).

UO126, in addition to inhibiting ERK1/2, also inhibits p90 ribosomal S6 kinase (RSK) (Zhang et al., 2002). To rule out the effect of UO126 on RSK, we used rapamycin, an inhibitor of RSK. Rapamycin (1-50 nM) did not prevent ammoniainduced astrocyte swelling (data not shown), indicating that the effect of UO126 was not through inhibition of RSK.

\section{MAPK inhibitors diminish ammonia- induced glutamate uptake inhibition} To examine whether MAPK inhibitors reverse ammonia-induced glutamate uptake inhibition, astrocyte cultures were treated with the above MAPK inhibitors, with or without $\mathrm{NH}_{4} \mathrm{Cl}(5 \mathrm{mM})$, for $3 \mathrm{~d}$. Cultures treated with $\mathrm{NH}_{4} \mathrm{Cl}$ significantly inhibited D-aspartate uptake (46\%, compared with control; $p<0.05)$. Treatment with SB239063 (10 $\mu \mathrm{M})$ and SP600125 (1 $\mu \mathrm{M})$ significantly reduced ammonia-induced D-aspartate uptake inhibition (88 and 79\%, respectively; $p<$ 0.05 compared with $\mathrm{NH}_{4} \mathrm{Cl}$ ), whereas the MEK1/2 inhibitor UO126 did not (Fig. 8). Cultures treated with higher doses of UO126 $(20,50$, or $100 \mu \mathrm{M})$, as well as vehicle, also had no effect on ammonia-induced glutamate uptake inhibition (data not shown). As with astrocyte swelling, we observed that addition of MAPK inhibitors immediately after the occurrence of the peak phosphorylation did not improve glutamate uptake inhibition. Likewise, a lower dose of ammonia (2 mM) did not cause glutamate uptake inhibition (data not shown).

\section{MAPK inhibitors reverse ammonia-induced decrease in GLAST protein levels}

We also determined whether the protective action of MAPK blockers on glutamate uptake inhibition was caused by an effect on the glutamate transporter. Western blot analysis showed a significant decrease in GLAST protein in cultures treated with 5
$\mathrm{mM} \mathrm{NH} \mathrm{NH}_{4} \mathrm{Cl}$ alone (38.8\%, compared with control; $\left.p<0.05\right)$. Although the decrease in GLAST is in agreement with our previous report showing a decrease in GLAST mRNA in cultured astrocytes exposed to ammonia (Zhou and Norenberg, 1999), the decline may also be attributable to, in part, increased protein degradation. Treatment with SB239063 and SP600125 significantly reversed the ammonia-induced decline in GLAST level (72 and $63 \%$, respectively; $p<0.05$, compared with $\mathrm{NH}_{4} \mathrm{Cl}$ ), whereas UO126 had no inhibitory effect (Fig. 9).

\section{Discussion}

This study demonstrates that key astroglial defects associated with HE such as cell swelling and glutamate uptake impairment can be attenuated by the use of antioxidants and NOS inhibition. Our studies also show that ammonia significantly enhances the phosphorylation of MAPKs, and that MAPK inhibitors reduce the severity of ammonia-induced astrocyte swelling and glutamate uptake inhibition. These findings lend support for a key role of oxidative stress and phosphorylation of MAPKs in the mechanism of ammonia neurotoxicity. 

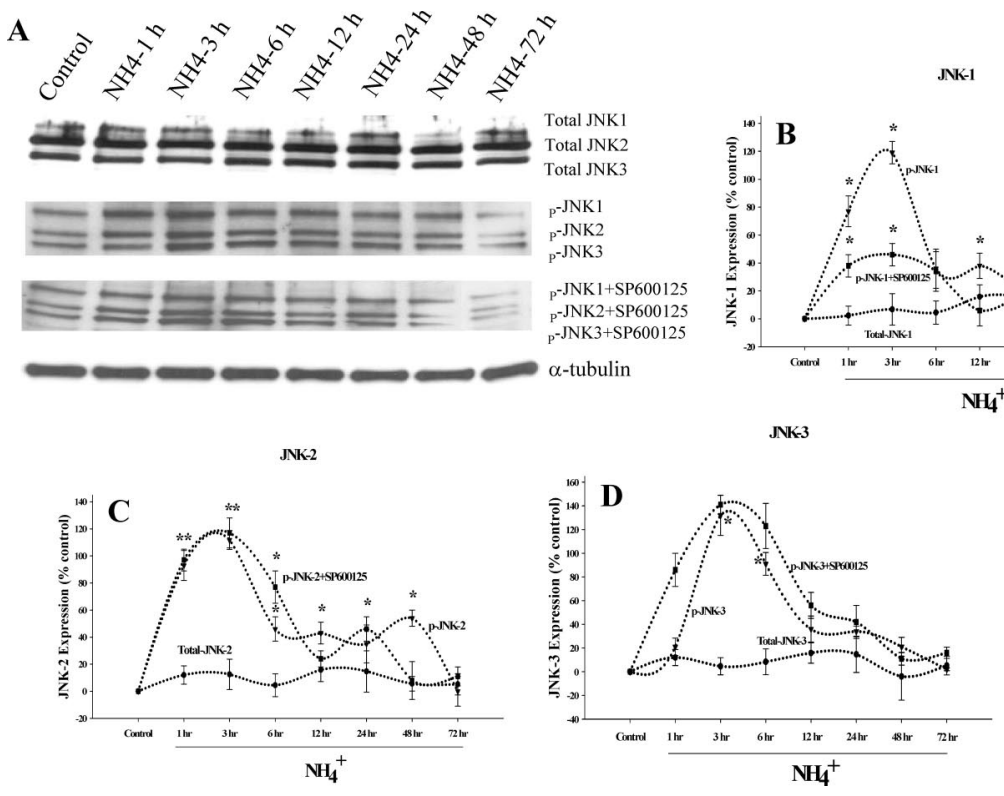

Figure 5. A, Time course of JNK $1 / 2 / 3$ phosphorylation by ammonia in cultured astrocytes. Western blot analysis reveals no significant change in total JNK1/2/3 level when cultures were exposed to $5 \mathrm{~mm} \mathrm{NH}_{4} \mathrm{Cl}$. A significant increase in the levels of phospho-JNK1/2/3 was observed after ammonia treatment. SP600125, a JNK inhibitor, partially prevented the ammonia-induced JNK1 phosphorylation but not JNK2 or JNK3. $\boldsymbol{B}-\boldsymbol{D}$, Quantitation of ammonia-induced changes in phospho-JNK1 (B), phosphoJNK2 (C), and phospho-JNK3 (D). Phospho-JNK1/2/3 levels are normalized against $\alpha$-tubulin. ANOVA, $n=5$. ${ }^{*} p<0.05$ versus control; ${ }^{\dagger} p<0.05$ versus $\mathrm{NH}_{4} \mathrm{Cl}$. Error bars represent mean \pm SEM.

\section{Oxidative/nitrosative stress in ammonia-induced astrocyte swelling}

Oxidative/nitrosative stress is an evolving concept in the pathogenesis of HE and ammonia neurotoxicity. There is evidence of lipid peroxidation in the brain of hyperammonemic mice (Kosenko et al., 1999). Ammonia increases superoxide production and decreases the activity of the antioxidant enzymes glutathione peroxidase, SOD, and catalase (Kosenko et al., 1997, 1999). Additionally, increased brain nitric oxide production is reported in portacaval-shunted rats after ammonia infusion (Master et al., 1999). Ammonia also increases free radical production, including nitric oxide, in cultured astrocytes (Murthy et al., 2001). Together, these studies strongly suggest the involvement of oxidative/nitrosative stress in ammonia neurotoxicity.

Oxidative stress has been proposed as an important factor in the development of cell swelling. Free radicals have been shown to cause cell swelling in brain slices (Chan et al., 1982, 1989; Brahma et al., 2000), as well as in cultured astrocytes (Chan et al., 1989; Cubells et al., 1994; Staub et al., 1994; Sharma, 1996; C. J. Chen et al., 2000). In keeping with these findings, our study shows that SOD, catalase, and vitamin $\mathrm{E}$ all significantly blocked astrocyte swelling caused by ammonia. L-NAME also significantly reduced ammonia-induced astrocyte swelling, consistent with findings reported by Zielinska et al. (2003), who showed that L-NAME prevented ammonia-induced swelling in brain slices.

Because L-NAME robustly attenuated cell swelling, it is likely that NO plays a major role in the ammonia-induced astrocyte swelling. In support of a role for NO in HE, NOS activity and gene expression have been shown to be elevated in experimental models of HE (Rao et al., 1997), and there is increased brain NO production in portacaval-shunted rats given ammonia infusions (Master et al., 1999). In addition, we found that the NO donors, SNAP and SIN-1, increased astrocyte swelling. Additional support is provided by Schliess et al. (2002), who showed protein tyrosine nitration after ammonia treatment in vivo and in vitro.
Collectively, these studies support a key role of oxidative and nitrosative stress in ammonia-induced astrocyte swelling.

\section{Antioxidants and NOS inhibition attenuate ammonia-induced inhibition of glutamate uptake}

Another important aspect of HE and hyperammonemia includes alterations in glutamatergic neurotransmission (Butterworth, 2001), likely because of failure of astrocytes to take up extracellular glutamate. In support of this, it has been shown that cultured astrocytes exposed to pathophysiological concentration of ammonia suppresses the high affinity uptake of glutamate in cultured astrocytes (Bender and Norenberg, 1996) and decreases GLAST mRNA levels in rat brain with acute liver failure (Knecht et al., 1997). Oxidative stress has been shown to inhibit glutamate uptake in cultured astrocytes (Volterra et al., 1994a,b; Y. Chen et al., 2000) and in rat brain synaptosomes (Berman and Hastings, 1997). Allen et al. (2001) showed that methylmercury-mediated inhibition of ${ }^{3} \mathrm{H}$-D-aspartate transport was reversed by the antioxidant catalase in cultured astrocytes. Volterra et al. (1994a) reported that xanthine plus xanthine oxidase-induced inhibition of glutamate transport was prevented by addition of SOD. Our findings are consistent with these observations in that the antioxidants SOD and vitamin E significantly attenuated the ammonia-induced inhibition of astrocytic glutamate uptake.

Cultures exposed to SNAP and SIN-1 significantly decreased glutamate uptake. Furthermore, L-NAME robustly prevented glutamate uptake inhibition, indicating an important role of $\mathrm{NO}$ in the mechanism of ammonia-induced astrocyte dysfunction. These results suggest that ammonia-induced inhibition of glutamate uptake, like astrocyte swelling, is mediated by oxidative/ nitrosative stress.

\section{MAPK phosphorylation by ammonia}

The above-mentioned results suggest that oxidative stress after ammonia exposure may be involved in the mechanism of ammonia-induced cell swelling and inhibition of glutamate uptake. However, the mechanism(s) by which oxidative stress results in these astroglial changes is still unknown. One important molecular consequence of oxidative stress is the activation of intracellular signaling cascades. Numerous studies indicate that reactive oxygen species (ROS) activate protein kinases (Remacle et al., 1995; Sen and Packer, 1996; Suzuki et al., 1997; Czaja et al., 2003). In particular, p38 ${ }^{\mathrm{MAPK}}$, JNK, and ERK1/2 are phosphorylated by exposure to exogenous $\mathrm{H}_{2} \mathrm{O}_{2}$, and this phenomenon can be inhibited by treatment with antioxidants (Abe et al., 1996; Guyton et al., 1996; Lo and Cruz, 1996). MAPK signaling cascades have also been shown to be activated in cultured astrocytes in response to oxidant signaling (Luo and Roth, 2000; Mizuhashi et al., 2000; S. H. Chen et al., 2001; Lennon et al., 2002).

Our study shows that ammonia increased the phosphorylation of ERK1/2, p38 ${ }^{\mathrm{MAPK}}$, and JNK. Similar findings were also observed by Schliess et al. (2002), who reported that cultured astrocytes exposed to ammonia increased the phosphorylation of 
A
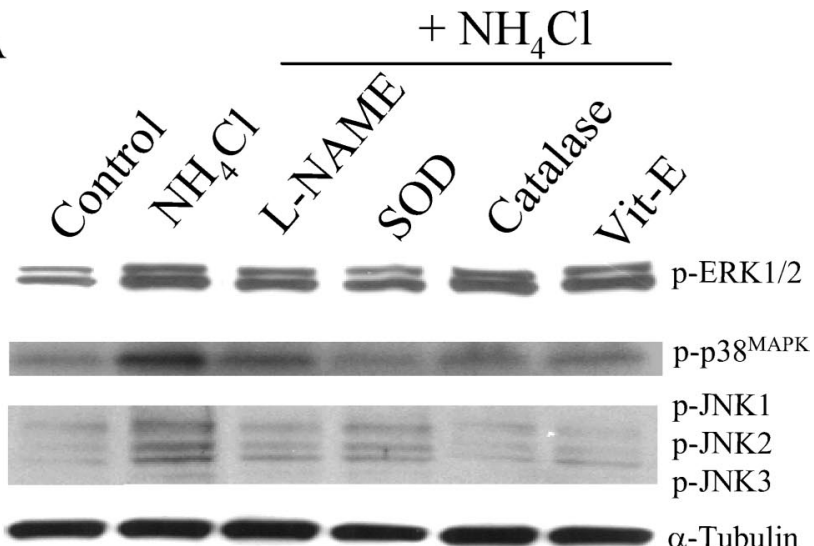

B

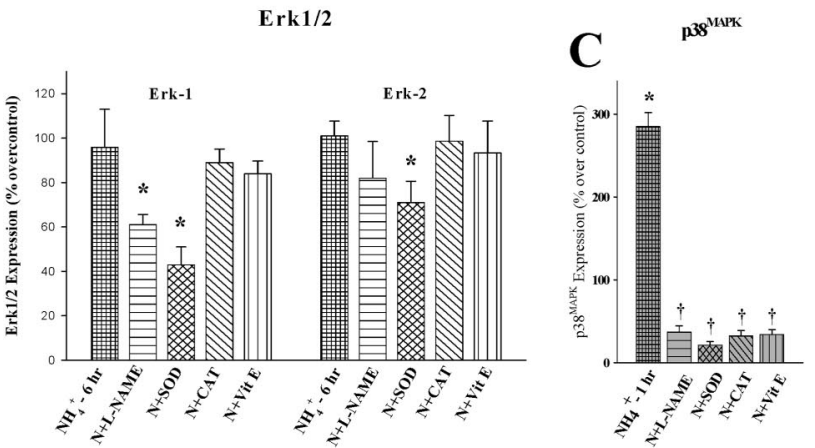

D

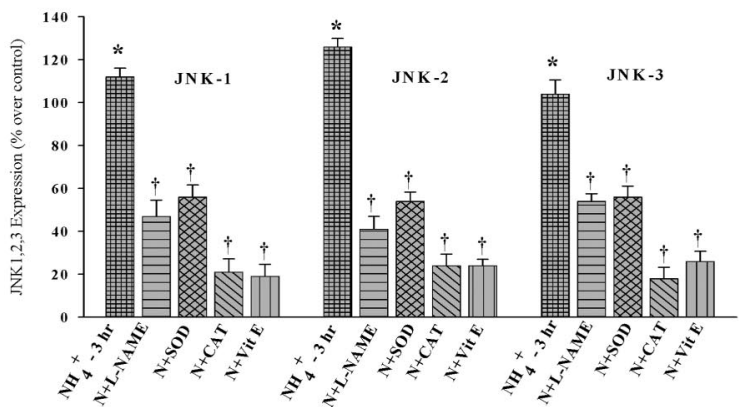

Figure 6. Antioxidants prevent ammonia-induced MAPK phosphorylation. Cultured astrocytes exposed to $5 \mathrm{~mm} \mathrm{NH}_{4} \mathrm{Cl}$ significantly increased phosphorylation of ERK1/2 (6h), JNK1/2/3 $(3 \mathrm{~h})$, and p38 $8^{\text {MAPK }}(1 \mathrm{~h})$. Treatment with SOD $(25 \mathrm{U} / \mathrm{ml})$ and L-NAME $(250 \mu \mathrm{M})$ (but not other antioxidants) significantly attenuated ammonia-induced ERK1 phosphorylation. SOD also inhibited the ERK2 phosphorylation. All antioxidants, as well as L-NAME, significantly decreased the phosphorylation level of both JNK1/2/3 and p38 MAPK. ANOVA, $n=3 .{ }^{*} p<0.05$ versus control; ${ }^{\dagger} p<0.05$ versus $\mathrm{NH}_{4} \mathrm{Cl}$. Vit-E, Vitamin E. Error bars represent mean $\pm \mathrm{SEM}$.

ERK 1 and $\mathrm{p} 38^{\mathrm{MAPK}}$ at $1 \mathrm{~d}$. In addition, we now show that ammonia increases the phosphorylation of JNK1/2/3. ERK1/2 and p38 ${ }^{\mathrm{MAPK}}$ were phosphorylated in a biphasic manner, although in contrast, JNK was only phosphorylated at earlier time points. The reason for the different time course of MAPK phosphorylation by ammonia is unknown. It is possible that the ERK1/2, p38 $8^{\text {MAPK }}$ and JNK1/2/3 might be differentially phosphorylated by upstream MAPK kinases in response to ROS generation (Fukunaga et al., 2000; Nègre-Aminou et al., 2002; Ding et al., 2002). For example, the ERK1/2 may be activated by the Ras/Raf pathway upstream of MEK1/2, whereas the JNK and $\mathrm{p} 38^{\mathrm{MAPK}}$ may be activated by Rac, an upstream kinase of MEK4/7 and MEK3/6 (Z. Chen et al., 2001). Therefore, differently activated Ras and Rac pathways by ammonia-induced oxidative stress may be respon-

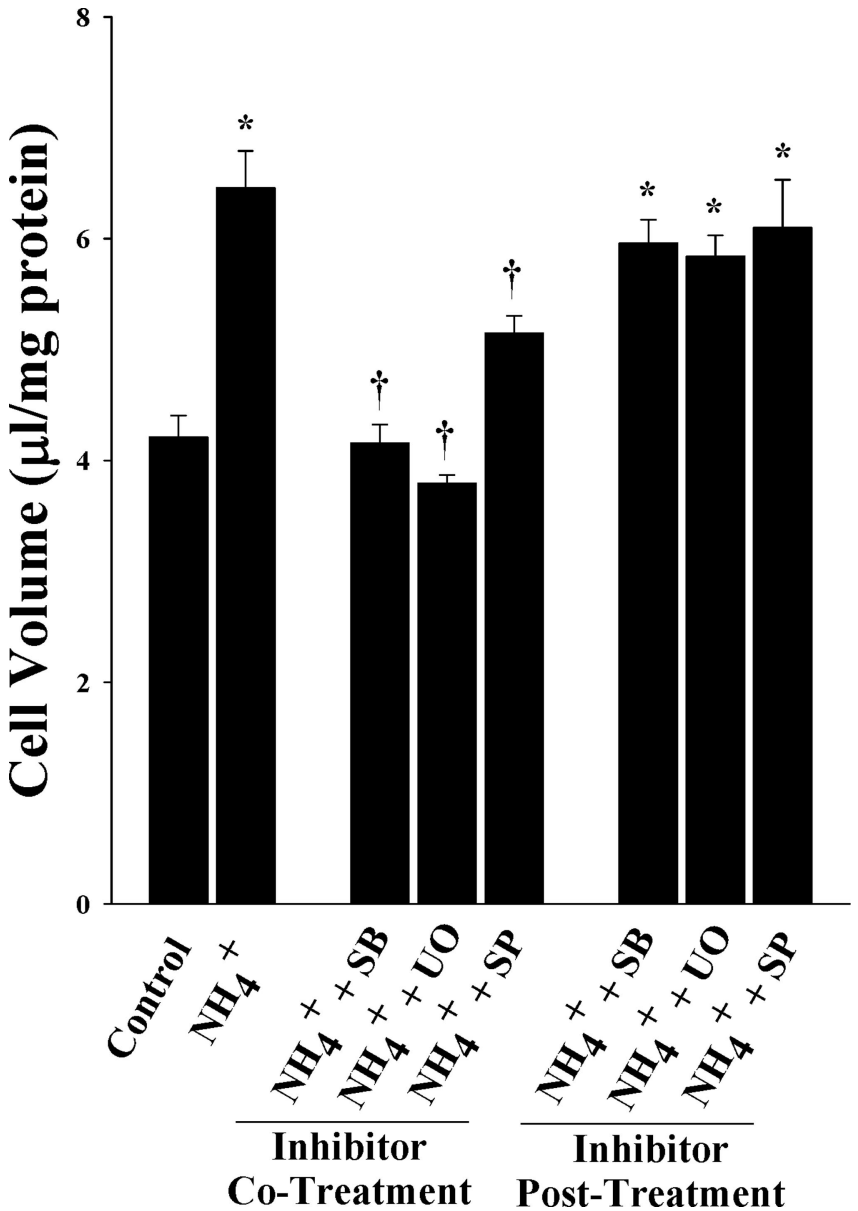

Figure 7. MAPK inhibitors prevent ammonia-induced astrocyte swelling. Cultured astrocytes exposed to $5 \mathrm{~mm} \mathrm{NH}_{4} \mathrm{Cl}$ significantly increased cell swelling (2 d). Cotreatment with SB239063 and U0126, p38 MAPK and ERK inhibitors, respectively, attenuated ammonia-induced astrocyte swelling. SP600125, a JNK inhibitor, partially diminished astrocyte swelling. ANOVA, $n=4{ }^{*} p<0.05$ versus control; ${ }^{\dagger} p<0.05$ versus ammonia. Posttreatment of MAPK inhibitors immediately after the peak phosphorylation of MAPKs by ammonia (U0126, $6 \mathrm{~h}$; SB239063, $1 \mathrm{~h}$; SP600125, 3 h) did not reduce cell swelling. U0, U0126; SB, SB239063; SP, SP600125. Error bars represent mean \pm SEM.

sible for the differential pattern of ERK1/2, p38 MAPK, and JNK phosphorylation. One possible explanation for the biphasic phosphorylation of ERK1/2 is that the first peak of ERK1/2 phosphorylation might be attributable to ROS generation (Canals et al., 2003; Clausen et al., 2004). The second peak might be attributable to the inactivation of mitogen-activated protein kinase phosphatase, which might occur in the second phase of ERK1/2 phosphorylation (Berlett and Stadtman, 1997; Camps et al., 1998; Muda et al., 1998). Although the pattern of activation of these kinases is different and its significance is unclear, as mentioned below, the early phosphorylation of MAPKs by ammonia appear to be critical for the ammonia-induced astrocyte dysfunction.

Antioxidants and NOS inhibition prevent ammonia-induced MAPK phosphorylation

Treatment with SOD but not vitamin E or catalase, significantly diminished the ammonia-induced phosphorylation of ERK1/2. Additionally, L-NAME significantly attenuated the cell swelling. All antioxidants tested in our study, including vitamin $\mathrm{E}$ and catalase, as well as L-NAME significantly diminished both JNK and $\mathrm{p} 38^{\mathrm{MAPK}}$ phosphorylation. It is unclear why SOD but not vitamin E prevented ERK1/2 phosphorylation, because both an- 


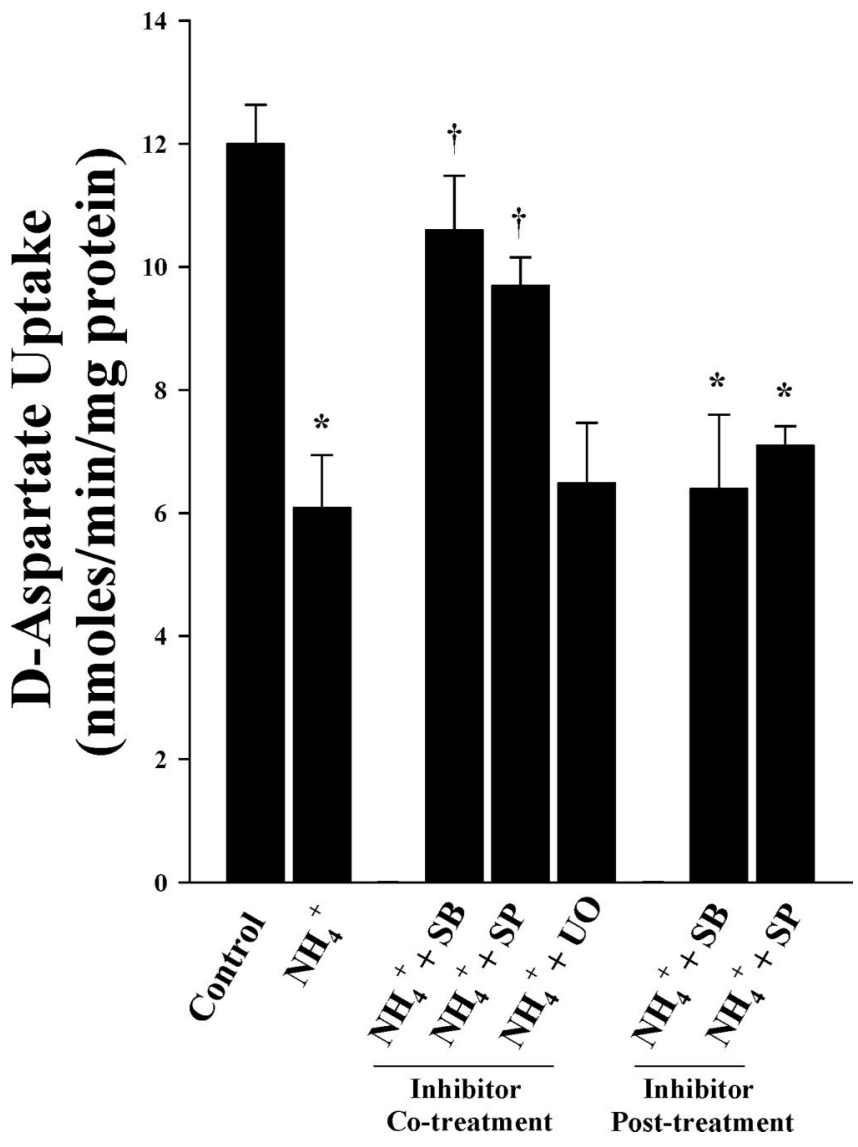

Figure 8. MAPK inhibitors reduce ammonia-induced glutamate uptake inhibition in cultured astrocytes. A 45\% decrease in glutamate uptake was observed when exposed to $5 \mathrm{~mm}$ $\mathrm{NH}_{4} \mathrm{Cl}(3 \mathrm{~d})$. Cotreatment with MAPKinhibitors SB239063 (p38 ${ }^{\mathrm{MAPK}}$ ) and SP600125 (JNK1/2/3), but not U0126 (ERK1/2), significantly diminished ammonia-induced glutamate uptake inhibition. ANOVA, $n=5 .{ }^{*} p<0.05$ versus control; ${ }^{\dagger} p<0.05$ versus ammonia. Posttreatment of MAPK inhibitors, as in Figure 7, did not reduce ammonia-induced glutamate uptake inhibition. UO, U0126; SB, SB239063; SP, SP600125. Error bars represent mean \pm SEM.

tioxidants can scavenge superoxide. Although vitamin E can scavenge both superoxide and NO, SOD and L-NAME are more potent in scavenging superoxide and NO, respectively (Osakada et al., 2003). It is possible that high levels of ammonia-induced superoxide and NO may generate peroxynitrite and that the effect of peroxynitrite may not be diminished by vitamin E. Thus, whereas ammonia increases phosphorylation of all these kinases, the free radical species involved in activating these various kinases may be different.

It should be noted that SOD is a large molecular weight protein, which is not freely permeable across the plasma membrane. Nevertheless, in our study, SOD diminished the astrocyte dysfunction produced by ammonia likely by quenching the superoxide radicals, which diffused out of the cell (Terada, 1996; Tolias et al., 1999; Murthy et al., 2001).

\section{MAPK inhibitors diminish astrocyte swelling}

Our results strongly implicate ERK $1 / 2$ and $\mathrm{p} 38^{\mathrm{MAPK}}$ as important kinases involved in ammonia-induced swelling, because such swelling was completely inhibited by UO126 (inhibitor of MEK1/2, the upstream kinase specific for ERK1/2) and SB239063 (inhibitor of p38 ${ }^{\mathrm{MAPK}}$ ). JNK inhibition by SP600125 only partially prevented ammonia-induced astrocyte swelling. However, SP600125 only inhibited the phosphorylation of JNK1 but not of JNK2/3. Whether the additional inhibition of JNK $2 / 3$ is also
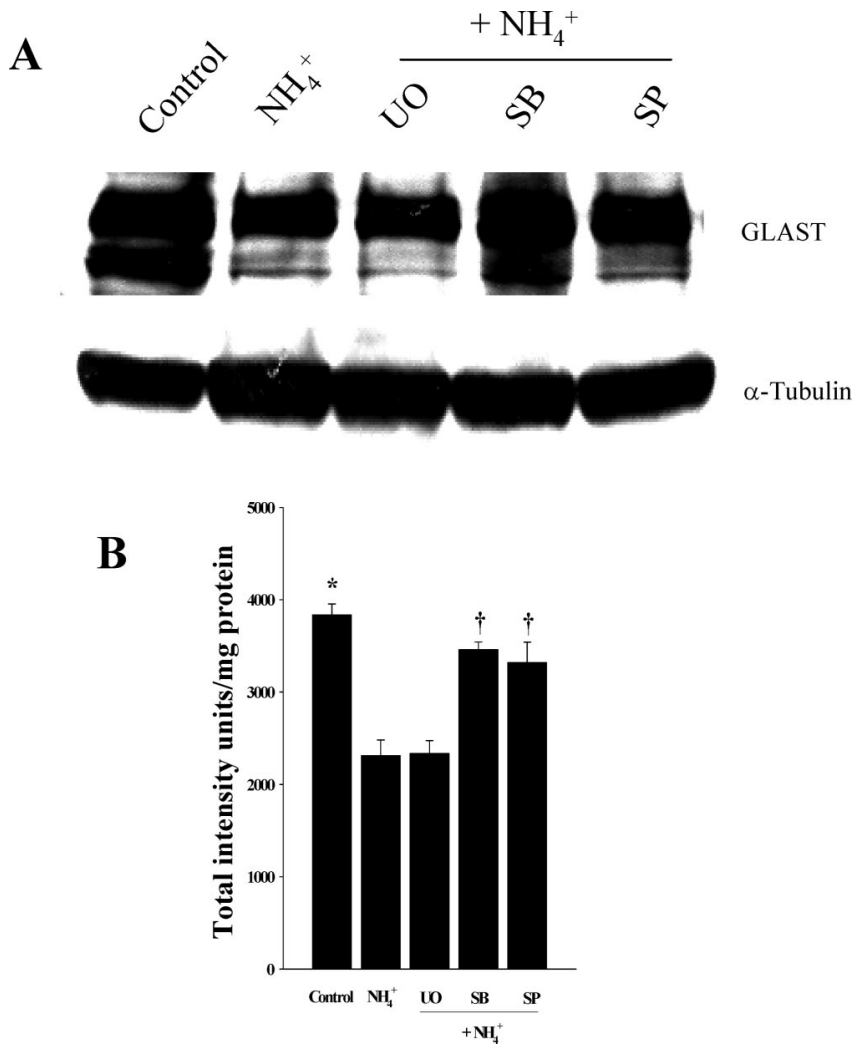

Figure 9. A, A representative Western blot showing a $38 \%$ decrease in GLAST protein levels in astrocyte cultures exposed to $5 \mathrm{~mm} \mathrm{NH}_{4} \mathrm{Cl}(3 \mathrm{~d}$ ). Treatment with MAPK inhibitors SB239063 (p38 ${ }^{\text {MAPK }}$ ) and SP600125 (JNK1/2/3), but not U0126 (ERK1/2), significantly abrogated the ammonia-induced decline in GLAST. $B$, Quantitation of GLAST levels normalized to $\alpha$-tubulin. ANOVA, $n=3$. ${ }^{*} p<0.05$ versus control; ${ }^{\dagger} p<0.05$ versus ammonia. U0, U0126; SB, SB239063; SP, SP600125. Error bars represent mean \pm SEM.

required to prevent astrocyte swelling is not known. Importantly, delayed addition of these inhibitors (after the peak phosphorylation of MAPKs) did not reduce astrocyte swelling, suggesting that early phosphorylation events induced by ammonia, and not the prolonged phosphorylation, is critical for astrocyte swelling.

Phosphorylation of MAPKs is known to occur after hypoosmotic swelling in cultured astrocytes (Crépel et al., 1998), human intestine 407 cells (Tilly et al., 1996), H4IIE rat hepatoma cells (Schliess et al., 1995), and isolated rat hepatocytes (Noe et al., 1996; Kim et al., 2000). These studies suggest that cell swelling may act as a stress signal to induce the phosphorylation of MAPKs. Our observations, in contrast, indicate that MAPK phosphorylation occurs before ammonia-induced swelling and that blockade of MAPKs diminishes astrocyte swelling. It appears that the role of kinases in the mediation of osmotic swelling and ammonia-induced swelling are different. However, it is important to note the difference in temporal sequence of swelling in these two conditions, with hypo-osmotic challenge resulting in almost immediate swelling, whereas with ammonia, the swelling is only first detected at $12 \mathrm{~h}$. The difference in rates of swelling may contribute to the pattern of MAPK phosphorylation.

Although it is possible that cell swelling induced by ammonia, rather than ammonia per se, may be the cause of MAPK phosphorylation, the increase in $\mathrm{p}$-JNK occurred before the onset of swelling, and thus the possibility that swelling is responsible for JNK phosphorylation can be discounted. As for ERK and p38 $8^{\text {MAPK }}$, whereas their peak phosphorylation occurred before the onset of swelling, the activation of these two kinases persisted 
during the period of swelling. Thus, the possibility that swelling may have contributed to ERK and $\mathrm{p} 38^{\mathrm{MAPK}}$ activation cannot be completely ruled out.

\section{MAPK inhibitors reduce glutamate uptake inhibition by ammonia}

Our results showed that ammonia significantly diminished glutamate uptake inhibition, which was prevented by inhibitors of p $38^{\mathrm{MAPK}}$ and JNK1/2/3 probably by preventing a decline in GLAST levels. Inhibition of ERK1/2 did not affect glutamate uptake inhibition. Abe and Misawa (2003) reported that $\beta$-amyloid-induced promotion of extracellular glutamate clearance (intracellular uptake) was enhanced in cultured astrocytes by the ERK1/2 inhibitor UO126. In both our study and theirs, an increase in ERK1/2 phosphorylation was detected after ammonia and $\beta$-amyloid treatment, respectively. However, inhibiting ERK1/2 in our study had no effect on glutamate uptake inhibition, suggesting that the role of ERK1/2 in glutamate transport is likely stress specific. Although p $38^{\mathrm{MAPK}}$ is involved in both swelling and glutamate uptake inhibition, ERK1/2 phosphorylation appears to mediate astrocyte swelling but not glutamate uptake inhibition. As with swelling, delayed treatment with inhibitors did not improve glutamate uptake inhibition.

Mechanisms underlying the differential effect of kinases on astrocyte dysfunction are not clear. It is known that activation of the Ras-Raf pathway leads to activation of MEK1/2 and subsequently of ERK1/2. But activation of Ras also activates MEK3 (Efimova et al., 2002), which then activates p38 ${ }^{\mathrm{MAPK}}$. In such a case, blockade of only ERK1/2 by UO126 may not be sufficient because of $\mathrm{p} 38^{\text {MAPK }}$ activation by the Ras-MEK3 pathway.

Inhibition of JNK almost completely prevented glutamate uptake inhibition but only partially prevented cell swelling. Whether the partial inhibition of swelling is attributable to partial inhibition of JNK is not clear, because SP600125 prevented phosphorylation of JNK1 but not JNK2/3. Nevertheless, blockade of JNK1 by SP600125 prevented glutamate uptake inhibition by ammonia, indicating an important role of JNK1 but not JNK2/3 in glutamate uptake inhibition. These results suggest that although ammonia activates all of these MAPKs, the kinases differentially contribute to astrocytic dysfunctions.

Our study links the early generation of ROS with MAPK phosphorylation and the subsequent development of astrocyte dysfunction. Although there is a time gap between kinase phosphorylation and astrocyte dysfunction, the reason for this gap is not clear. A likely explanation is that the MAPKs activate downstream targets, including kinases and transcription factors ( $Z$. Chen et al., 2001), to eventually bring about the observed astroglial abnormalities.

In summary, our study shows that ammonia-induced astrocyte swelling and inhibition of glutamate uptake is mediated through oxidative and/or nitrosative stress-induced phosphorylation of MAPKs. Antioxidants and inhibition of MAPKs blocked or attenuated these major aspects of ammonia neurotoxicity. Treatment aimed at diminishing oxidative stress or modulating MAPK phosphorylation might represent useful therapeutic approaches in $\mathrm{HE}$ and other hyperammonemic states.

\section{References}

Abe J, Kusuhara M, Ulevitch RJ, Berk BC, Lee JD (1996) Big mitogenactivated protein kinase 1 (BMK1) is a redox-sensitive kinase. J Biol Chem 271:16586-16590.

Abe K, Misawa M (2003) Amyloid $\beta$ protein enhances the clearance of extracellular $\beta$-glutamate by cultured rat cortical astrocytes. Neurosci Res 45:25-31.
Aikawa R, Komuro I, Yamazaki T, Zou Y, Kudoh S, Tanak M, Shiojima I, Hiro Y, Yazaki Y (1997) Oxidative stress activates extracellular signalregulated kinases through $\mathrm{Src}$ and Ras in cultured cardiac myocytes of neonatal rats. J Clin Invest 100:1813-1821.

Albrecht J, Jones EA (1999) Hepatic encephalopathy: molecular mechanisms underlying the clinical syndrome. J Neurol Sci 170:138-146.

Allen JW, Mutkus LA, Aschner M (2001) Methylmercury-mediated inhibition of ${ }^{3} \mathrm{H}$-D-aspartate transport in cultured astrocytes is reversed by the antioxidant catalase. Brain Res 902:92-100.

Bender AS, Norenberg MD (1996) Effects of ammonia on L-glutamate uptake in cultured astrocytes. Neurochem Res 21:567-573.

Bender AS, Norenberg MD (1998) Effect of benzodiazepines and neurosteroids on ammonia-induced swelling in cultured astrocytes. J Neurosci Res 54:673-680.

Bender AS, Woodbury DM, White HS (1989) Beta-DL-methyleneaspartate, an inhibitor of aspartate aminotransferase, potently inhibits L-glutamate uptake into astrocytes. Neurochem Res 14:641-646.

Berlett BS, Stadtman ER (1997) Protein oxidation in aging, disease, and oxidative stress. J Biol Chem 272:20313-20316.

Berman SB, Hastings TG (1997) Inhibition of glutamate transport in synaptosomes by dopamine oxidation and reactive oxygen species. J Neurochem 69:1185-1195.

Bismuth H, Samuel D, Castaing D, Williams R, Pereira SP (1996) Liver transplantation in Europe for patients with acute liver failure. Semin Liver Dis 16:415-425.

Bosman DK, Deutz NE, de Graaf AA, van Eijk HM, Bovee WM, Maas MA, Jorning GG, Chamuleau RA (1990) Changes in brain metabolism during hyperammonemia and acute liver failure: results of a comparative 1H-NMR spectroscopy and biochemical investigation. Hepatology 12:281-290.

Brahma B, Forman RE, Stewart EE, Nicholson C, Rice ME (2000) Ascorbate inhibits edema in brain slices. J Neurochem 74:1263-1270.

Butterworth RF (2001) Neurotransmitter dysfunction in hepatic encephalopathy: new approaches and new findings. Metab Brain Dis 16:55-65.

Camps M, Nichols A, Gillieron C, Antonsson B, Muda M, Chabert C, Boschert U, Arkinstall S (1998) Catalytic activation of the phosphatase MKP-3 by ERK2 mitogen-activated protein kinase. Science 280:1262-1265.

Canals S, Casarejos MJ, de Bernardo S, Solano RM, Mena MA (2003) Selective and persistent activation of extracellular signal-regulated protein kinase by nitric oxide in glial cells induces neuronal degeneration in glutathione-depleted midbrain cultures. Mol Cell Neurosci 24:1012-1026.

Capocaccia L, Angelico M (1991) Fulminant hepatic failure: clinical features, etiology, epidemiology and current management. Dig Dis Sci 36:775-779.

Chan PH, Yurko M, Fishman RA (1982) Phospholipid degradation and cellular edema induced by free radicals in brain cortical slices. J Neurochem 38:525-531.

Chan PH, Longar S, Chen S, Yu AC, Hillered L, Chu L, Imaizumi S, Pereira B, Moore K, Woolworth V (1989) The role of arachidonic acid and oxygen radical metabolites in the pathogenesis of vasogenic brain edema and astrocytic swelling. Ann NY Acad Sci 559:237-247.

Chen CJ, Liao SL, Kuo JS (2000) Gliotoxic action of glutamate on cultured astrocytes. J Neurochem 75:1557-1565.

Chen SH, Liu SH, Liang YC, Lin JK, Lin-Shiau SY (2001) Oxidative stress and c-Jun-amino-terminal kinase activation involved in apoptosis of primary astrocytes induced by disulfiram-Cu $(2+)$ complex. Eur J Pharmacol 414:177-188.

Chen Y, Ying W, Simma V, Copin JC, Chan PH, Swanson RA (2000) Overexpression of $\mathrm{Cu}, \mathrm{Zn}$ superoxide dismutase attenuates oxidative inhibition of astrocyte glutamate uptake. J Neurochem 75:939-945.

Chen Z, Gibson TB, Robinson F, Silvestro L, Pearson G, Xu B, Wright A, Vanderbilt C, Cobb MH (2001) MAP kinases. Chem Rev 101:2449-2476.

Clausen F, Lundqvist H, Ekmark S, Lewén A, Ebendal T, Hillered L (2004) Oxygen free radical-dependent activation of extracellular signalregulated kinase mediates apoptosis-like cell death after traumatic brain injury. J Neurotrauma 21:1168-1182.

Crépel V, Panenka W, Kelly ME, MacVicar BA (1998) Mitogen-activated protein and tyrosine kinases in the activation of astrocyte volumeactivated chloride current. J Neurosci 18:1196-1206. 
Cubells JF, Rayport S, Rajendran G, Sulzer D (1994) Methamphetamine neurotoxicity involves vacuolation of endocytic organelles and dopamine-dependent intracellular oxidative stress. J Neurosci 14:2260-2271.

Czaja MJ, Liu H, Wang Y (2003) Oxidant-induced hepatocyte injury from menadione is regulated by ERK and AP-1 signaling. Hepatology 37:1405-1413.

Dejong CH, Kampman MT, Deutz NE, Soeters PB (1992) Cerebral cortex ammonia and glutamine metabolism during liver insufficiency-induced hyperammonemia in the rat. J Neurochem 59:1071-1079.

de Knegt RJ, Schalm SW, van der Rijt CC, Fekkes D, Dalm E, HekkingWeyma I (1994) Extracellular brain glutamate during acute liver failure and during acute hyperammonemia stimulatory acute liver failure: an experimental study based on in vivo brain dialysis. J Hepatol 20:19-26.

Ding M, Li J, Leonard SS, Shi X, Costa M, Castranova V, Vallyathan V, Huang C (2002) Differential role of hydrogen peroxide in UV-induced signal transduction. Mol Cell Biochem 234-235:81-90.

Drejer J, Larsson OM, Schousboe A (1982) Characterization of L-glutamate uptake into and release from astrocytes and neurons cultured from different brain regions. Exp Brain Res 47:259-269.

Ducis I, Norenberg LOB, Norenberg MD (1990) The benzodiazepine receptor in cultured astrocytes from genetically epilepsy-prone rats. Brain Res 531:318-321.

Efimova T, Deucher A, Kuroki T, Ohba M, Eckert RL (2002) Novel protein kinase $\mathrm{C}$ isoforms regulate human keratinocyte differentiation by activating a p38 delta mitogen-activated protein kinase cascade that targets CCAAT/enhancer-binding protein alpha. J Biol Chem 277:31753-31760.

Fukunaga K, Noguchi T, Takeda H, Matozaki T, Hayashi Y, Itoh H, Kasuga M (2000) Requirement for protein-tyrosine phosphatase SHP-2 in insulininduced activation of c-Jun $\mathrm{NH}_{2}$-terminal kinase. J Biol Chem 275:5208-5213.

Ganz R, Swain M, Traber P, DalCanto M, Butterworth RF, Blei AT (1989) Ammonia-induced swelling of rat cerebral cortical slices: implications for the pathogenesis of brain edema in acute hepatic failure. Metab Brain Dis 4:213-223.

Guyton KZ, Liu Y, Gorospe M, Xu Q, Holbrook NJ (1996) Activation of mitogen-activated protein kinase by $\mathrm{H}_{2} \mathrm{O}_{2}$. Role in cell survival following oxidant injury. J Biol Chem 271:4138-4142.

Hazell AS, Butterworth RF (1999) Hepatic encephalopathy: an update of pathophysiologic mechanisms. Proc Soc Exp Biol Med 222:99-112.

Hindfelt B, Plum F, Duffy TE (1977) Effect of acute ammonia intoxication on cerebral metabolism in rats with portacaval shunts. J Clin Invest 59:386-396.

Kim RD, Darling CE, Cerwenka H, Chari RS (2000) Hypoosmotic stress activates p38, ERK1 and 2, and SAPK/JNK in rat hepatocytes. J Surg Res 90:58-66.

Kimelberg HK (1987) Anisotonic media and glutamate-induced ion transport and volume responses in primary astrocyte cultures. J Physiol (Paris) 82:294-303.

Kletzein RF, Pariza MW, Becker JE, Potter VR (1975) A method using 3-Omethyl-D-glucose and phloretin for the determination of intracellular water space of cells in monolayer culture. Ann Biochem 68:537-544.

Knecht K, Michalak A, Rose C, Rothstein JD, Butterworth RF (1997) Decreased glutamate transporters (GLT-1) expression in frontal cortex of rats with acute liver failure. Neurosci Lett 229:201-203.

Kosenko E, Kaminsky Y, Kaminsky A, Valencia M, Lee L, Hermenegildo C, Felipo V (1997) Superoxide production and antioxidant enzymes in ammonia intoxication in rats. Free Rad Res 27:637-644.

Kosenko E, Kaminski Y, Lopata O, Muravyov N, Felipo V (1999) Blocking NMDA receptors prevents the oxidative stress induced by acute ammonia intoxication. Free Rad Biol Med 26:1369-1374.

Kyriakis JM, Avruch J (1996) Protein kinase cascades activated by stress and inflammatory cytokines. Bioessays 18:567-577.

Lennon AM, Ramauge M, Dessouroux A, Pierre M (2002) MAP kinase cascades are activated in astrocytes and preadipocytes by 15 -deoxy-delta (12-14)-prostaglandin $\mathrm{J}(2)$ and the thiazolidinedione ciglitazone through peroxisome proliferator activator receptor gamma-independent mechanisms involving reactive oxygenated species. J Biol Chem 277:29681-29685.

Levin LH, Koehler RC, Brusilow SW, Jones J, Traystman RJ (1989) Elevated brain water during urease-induced hyperammonemia in dogs. In: Intracranial pressure (Hoff JT, Betz AL, eds), pp 1032-1034. Berlin: Springer.
Lo YYC, Cruz TF (1996) Reactive oxygen species mediate cytokine activation of c-Jun NH2-terminal kinases. J Biol Chem 271:15703-15707.

Lockwood AH (1992) Hepatic encephalopathy. Boston: Butterworth-Heinemann.

Luo Y, Roth GS (2000) The roles of dopamine oxidative stress and dopamine receptor signaling in aging and age-related neurodegeneration. Antioxid Redox Signal 2:449-460.

Marcaida G, Felipo V, Hermengildo C, Minana MD, Grisolia S (1992) Acute ammonia toxicity is mediated by the NMDA type of glutamate receptors. FEBS Lett 296:67-68.

Martinez AJ (1968) Electron microscopy in human hepatic encephalopathy. Acta Neuropathol (Berl) 11:82-86.

Master S, Gottstein J, Blei AT (1999) Cerebral blood flow and the development of ammonia-induced brain edema in rats after portacaval anastomosis. Hepatology 30:876-880.

Mielke K, Herdegen T (2000) JNK and p38 stress kinases-degenerative effectors of signal-transduction-cascades in the nervous system. Prog Neurobiol 61:45-60.

Mizuhashi S, Ikegaya Y, Nishiyama N, Matsuki N (2000) Cortical astrocytes exposed to tributyltin undergo morphological changes in vitro. Jpn J Pharmacol 84:339-346.

Moroni F, Lombardi G, Moneti G, Cortesini C (1983) The release and the neosynthesis of glutamic acid are increased in experimental models of hepatic encephalopathy. J Neurochem 40:850-854.

Muda M, Theodosiou A, Gillieron C, Smith A, Chabert C, Camps M, Boschert U, Rodrigues N, Davies K, Ashworth A, Arkinstall S (1998) The mitogen-activated protein kinase phosphatase- $3 \mathrm{~N}$-terminal noncatalytic region is responsible for tight substrate binding and enzymatic specificity. J Biol Chem 273:9323-9329.

Murthy ChRK, Rama Rao KV, Bai G, Norenberg MD (2001) Ammonia induced production of free radicals in primary cultures of rat astrocytes. J Neurosci Res 66:282-288.

Nègre-Aminou P, van Leeuwen RE, van Thiel GC, van den IJssel P, de Jong WW, Quinlan RA, Cohen LH (2002) Differential effect of simvastatin

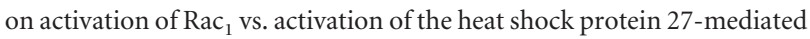
pathway upon oxidative stress, in human smooth muscle cells. Biochem Pharmacol 64:1483-1491.

Noe B, Schliess F, Wettstein M, Heinrich S, Häussinger D (1996) Regulation of taurocholate excretion by a hypo-osmolarity-activated signal transduction pathway in rat liver. Gastroenterology 110:858-865.

Norenberg MD (1977) A light and electron microscopic study of experimental portal-systemic (ammonia) encephalopathy. Progression and reversal of the disorder. Lab Invest 36:618-627.

Norenberg MD (2001) Astrocytes and ammonia in hepatic encephalopathy In: Astrocytes in the aging brain (de Vellis J, ed), pp 477-496. Totowa, NJ: Humana.

Norenberg MD (2003) Oxidative and nitrosative stress in ammonia neurotoxicity. Hepatology 37:245-248.

Norenberg MD, Baker L, Norenberg LO, Blicharska J, Bruce-Gregorios JH, Neary JT (1991) Ammonia-induced astrocyte swelling in primary culture. Neurochem Res 16:833-836.

Norenberg MD, Huo Z, Neary JT, Roig-Cantesano A (1997) The glial glutamate transporter in hyperammonemia and hepatic encephalopathy: relation to energy metabolism and glutamatergic neurotransmission. Glia 21:124-133.

Ono K, Han J (2000) The p38 signal transduction pathway: activation and function. Cell Signal 12:1-13.

Osakada F, Hashino A, Kume T, Katsuki H, Kaneko S, Akaike A (2003) Neuroprotective effects of $\alpha$-tocopherol on oxidative stress in rat striatal cultures. Eur J Pharmacol 465:15-22.

Plum F, Hindfelt B (1976) The neurological complication of liver disease. In: Handbook of clinical neurology, Vol 27 (Vinken PJ, Bruyn GW eds), pp 349-377. Amsterdam: North-Holland.

Raabe W (1989) Ammonium decreases excitatory synaptic transmission in cat spinal cord in vivo. J Neurophysiol 62:1461-1473.

Rama Rao KV, Chen M, Simard JM, Norenberg MD (2003) Suppression of ammonia-induced astrocyte swelling by cyclosporin A. J Neurosci Res 74:891-897.

Rao VLR, Audet M, Butterworth RF (1997) Increased neuronal nitric oxide synthase expression in brain following portacaval anastomosis. Brain Res 765:169-172.

Remacle J, Raes M, Toussaint O, Renard P, Rao G (1995) Low levels of 
reactive oxygen species as modulators of cell function. Mutat Res 316:103-122.

Schliess F, Schreiber R, Häussinger D (1995) Activation of extracellular signal-regulated kinases ERK-1 and ERK-2 by cell swelling in H4IIE hepatoma cells. Biochem J 309:13-17.

Schliess F, Görg B, Fischer R, Desjardins P, Bidmon HJ, Herrmann A, Butterworth RF, Zilles K, Häussinger D (2002) Ammonia induces MK-801sensitive nitration and phosphorylation of protein tyrosine residues in rat astrocytes. FASEB J 16:739-741.

Sen CK, Packer L (1996) Antioxidant and redox regulation of gene transcription. FASEB J 10:709-720.

Sharma P (1996) Effect of ascorbic acid on hyperoxic rat astrocytes. Neuroscience 72:391-397.

Staub F, Winkler A, Peters J, Kempski O, Kachel V, Baethmann A (1994) Swelling, acidosis, and irreversible damage of glial cells from exposure to arachidonic acid in vitro. J Cereb Blood Flow Metab 14:1030-1039.

Suzuki YJ, Forman HJ, Sevanian A (1997) Oxidants as stimulators of signal transduction. Free Radic Biol Med 22:269-285.

Swain M, Butterworth RF, Blei AT (1992) Ammonia and related amino acids in the pathogenesis of brain edema in acute ischemic liver failure in rats. Hepatology 15:449-453.

Takahashi H, Koehler RC, Brusilow SW, Traystman RJ (1991) Inhibition of brain glutamine accumulation prevents cerebral edema in hyperammonemia in rats. Am J Physiol 281:H826-H829.

Terada LS (1996) Hypoxia-reoxygenation increases $\mathrm{O}_{2}{ }^{-}$efflux which injures endothelial cells by an extracellular mechanism. Am J Physiol 270:H945-H950.

Tilly BC, Gaestel M, Engel K, Edixhoven MJ, de Jonge HR (1996) Hypoosmotic cell swelling activates the p38 MAP kinase signalling cascade. FEBS Lett 395:133-136.

Tolias CM, McNeil CJ, Kazlauskaite J, Hillhouse EW (1999) Superoxide generation from constitutive nitric oxide synthase in astrocytes in vitro regulates extracellular nitric oxide availability. Free Radic Biol Med 26:99-106.

Tossman U, Delin A, Eriksson LS, Ungerstedt U (1987) Brain cortical amino acids measured by intracerebral dialysis in portacaval shunted rats. Neurochem Res 12:265-269.

Traber P, DalCanto M, Ganger D, Blei AT (1989) Effect of body temperature on brain edema and encephalopathy in the rat after hepatic devascularization. Gastroenterology 96:885-891.

Vaquero J, Chung C, Blei AT (2003) Brain edema in acute liver failure. A window to the pathogenesis of hepatic encephalopathy. Ann Hepatol 2:12-22.

Volterra A, Trotti D, Tromba C, Floridi S, Racagni G (1994a) Glutamate uptake inhibition by oxygen free radicals in rat cortical astrocytes. J Neurosci 14:2924-2932.

Volterra A, Trotti D, Racagni G (1994b) Glutamate uptake is inhibited by arachidonic acid and oxygen radicals via two distinct and additive mechanisms. Mol Pharmacol 46:986-992.

Voorhies TM, Ehrlich ME, Duffy TE, Petito CK, Plum F (1983) Acute hyperammonemia in the young primate. Physiologic and neuropathological correlates. Pediatr Res 17:970-975.

Zhang Y, Zhai Q, Luo Y, Dorf ME (2002) RANTES-mediated chemokine transcription in astrocytes involves activation and translocation of p90 ribosomal S6 protein kinase (RSK). J Biol Chem 277:19042-19048.

Zhou BG, Norenberg MD (1999) Ammonia downregulates GLAST mRNA glutamate transporter in rat astrocyte cultures. Neurosci Lett 10:145-148.

Zielinska M, Law RO, Albrecht J (2003) Excitotoxic mechanism of cell swelling in rat cerebral cortical slices treated acutely with ammonia. Neurochem Int 43:299-303.

Zwingmann C, Flögel U, Pfeuffer J, Leibfritz D (2000) Effect of ammonia exposition on glioma cells: changes in cell volume and organic osmolytes studied by diffusion-weighted and high-resolution NMR spectroscopy. Dev Neurosci 22:463-471. 